\title{
Increasing Students' English Vocabulary by Applying Games and Songs at the Seventh Grade of SMP Negeri 8 Komodo
}

\author{
Aloysia Moto \\ SMPN 8 KOMODO Labuan Bajo, email: aloysiamoto@gmail.com \\ Junus Ludji Djonga \\ DINAS PKO SABU RAIJUA, email: dljongaadriancassano@gmail.com \\ Armi Reinnati \\ SMA YASMOR Oenoni, email: armireinnati33@gmail.com \\ Sulistyaningsih \\ STKIP PGRI Sidoarjo, email: $\underline{\text { ulistyaningsih3112@gmail.com }}$
}

\begin{abstract}
This research aimed to know whether by applying games and songs can increase students' vocabulary. It was conducted at seventh grade of SMPN 8 Komodo. Games are a way to relax class routines for fun, games also can make students enthusiastic about playing, sometimes challenging. Songs be trusted to help students in memorizing vocabulary. Memorizing song can be used to increase students'vocabulary. The students' responses showed that they were interested in learning vocabulary through using games and songs. It can be seen from the students' score on vocabulary test which increased from three vocabulary tests given in the Cycle I and Cycle II. In the students' achievement Cycle I was 57,5 and Cycle II was 77,5. It can be concluded that games and songs have a significant impact on increasing students' vocabulary number.
\end{abstract}

Keywords:Games, English songs, vocabulary.

\section{INTRODUCTION}

The total number of words that make up a language is referred to as its vocabulary. Using this definition, we can determine the number of known words, as well as the rules for putting them together to form a language. This means that knowing the meaning of words as well as how they are used in context is part of developing one's vocabulary. The use of vocabulary is one aspect of language that must be taken into consideration. In order to learn and understand a language, it is necessary to go through this process. Vocabulary can be defined as the knowledge of words and their meanings in general terms. For the purposes of this article, we refer to vocabulary as the types of 
Increasing Students' English Vocabulary by Applying Games and Songs at the Seventh Grade of SMP Negeri 8 Komodo

words that students must be familiar with in order to read texts that are becoming increasingly demanding to comprehend (Nurdiansyah, Asyid \& Parmawati, 2019).

"Vocabulary" refers to a collection of words that we all know and that we hear on a regular basis when conversing with another person. Thus, the vocabulary serves as both a means of archiving words and a tool for communication in the language classroom. Generally speaking, the more vocabulary that is familiar or frequently heard in the brain, the more quickly the brain will recall it. When learning a foreign language, such as English, one of the most important things to concentrate on is the vocabulary that is used in the language. In addition to grammar, vocabulary plays an important role in the process of learning a foreign language. It will be extremely difficult for someone who wishes to communicate to navigate the translation process because he or she does not have sufficient vocabulary storage. It is the same outcome that we will have if we try to listen to what other people have to say about themselves. If we haven't heard a single word that he or she has ever said before, it will be difficult to understand. If one does not have a large vocabulary in English, it is impossible to communicate effectively in that language (Bridge \& Burton, 1982). According to research, learning a foreign language's vocabulary is extremely important. This is especially true when learning the English language, which has a large and diverse range of vocabulary.

Both students and teachers find it challenging, and it takes many different approaches from both parties in order for the teacher to effectively communicate and the students to accept the new information and procedures. In general, teachers employ traditional methods of teaching vocabulary to their students. Additionally, because there is no media used and only verbal descriptions of a state/form/place are given to students instead of seeing the form/situation directly, students must rely on their imaginations to understand the meaning of the difficult words. Thus, it is difficult for him to comprehend the meaning being conveyed by the teacher in this situation. Students become less interested in learning and pay less attention to their teachers as a result of this fact.

Based on the information presented above, teachers must be innovative in the classroom in order to pique the interest of students in English. So their enthusiasm for English will serve as a crucial foundation for developing more satisfying English language abilities in the future. The teacher must employ a variety of methods in order 
Increasing Students' English Vocabulary by Applying Games and Songs at the Seventh Grade of SMP Negeri 8 Komodo

for students to fully comprehend the subject matter, and he must do so in a way that demonstrates how important vocabulary is in mastering the English language.

\section{Definition of Songs}

There are many different types of media available today for teaching vocabulary to students; one of the most popular is the English song. The use of English songs in the classroom can help to improve the quality of vocabulary learned during the teaching and learning process. Due to the fact that music can motivate students to learn new words that they have already heard, this occurred. According to Griffe (2001), song is a form of music that is performed through the use of words. Cebula (2008) also states that students who participate in song-based learning are more likely to express themselves freely and to learn a large number of new words. Another previous study related to the implementation of English song as a media for teaching vocabulary comes from the University of California (Setia, 2012). In her research, she attempted to determine the effectiveness of using songs in the classroom when teaching English to primary school students. During her research, she discovered that the use of songs not only assists students in improving their language proficiency, but it also stimulates and increases the students' interest in learning, as well as their enjoyment and participation in the learning process.

Songs can help students achieve a healthy balance between their intellectual and emotional intelligence, resulting in improved academic performance. It is possible for songs to stimulate brain function; the meaning of songs can provide stimulation for the development of memory functions, as well as for the acquisition of vocabulary, language, listening, and speaking skills. In order for students to integrate themselves into English, they require a method of instruction that is both practical and enjoyable. For example, singing English songs can help students integrate themselves into English (Gushendra, 2017). There are numerous advantages to incorporating songs into language learning activities. For starters, they can encourage students to communicate in English. Students can better understand and support words and meanings when they are listening to English songs, which are supported by images and actions in the song's compilation. Finally, songs can elicit a positive emotional response to the process of learning a new language. 
Increasing Students' English Vocabulary by Applying Games and Songs at the Seventh Grade of SMP Negeri 8 Komodo

Students can also acquire and learn foreign languages by using songs. Memorizing songs is believed to make students interested, songs can also help them learn vocabulary more easily (Dewi, 2013). Songs can be a great source of study for an English class. This is because some students well know the songs in English. Classes can also be fun and enjoyable learning. It doesn't take a lot of time or meetings to be held (Agustina, 2016).

\section{Definition of Games}

Andrew Wright, David Betteridge and Michael Buckby stated in "Games for Language Learning book'... 'Game' to an activity which is entertaining and engaging, often challenging, and an activity in which learners play and usually interact with others. It means that game is interesting things, because games might make students enthusiastic to play it, sometimes it is challenging because when students are playing games, they have to be a winner in that games and it is also entertaining because students' fun and enjoy in playing and interacting each other.

Games itself can be defined as a form usual competitive play or sport that need the duration of time rule. It can be used in order to give practice in all language skills and they can help the teacher or instructor to create the interesting and amusing context of learning. It cal also be used to teach a variety of language items such as sentence patterns, vocabulary, pronunciation, rhythm, adjectives, and adverbs and so on.

According to Brumfit (1995: 142), children play and children learn through playing. In playing together, children interacts with their friends and they develop language skill. Games provides context for play, reasons for playing and routines for playing. Games are activities that children naturally and universally engage in. There is a certain timelessness in the pleasure children find games and in how the nature of the play changes as they develop, ranging through fantasy, ritual, competition and luck. Generations of children rediscover some games and delight in plsying them. Games maybe seen as a route by which children come to terms with their social environment, presenting as they do social environment, presenting as they do a social situation which is firmly governed by rules but shows out come is unknown. Piaget (1967:80) saw children's games as the most admirable social institutions. Using games may certainly be an effective way of making repetition of language natural and purposeful for young 
Increasing Students' English Vocabulary by Applying Games and Songs at the Seventh Grade of SMP Negeri 8 Komodo

learners. Many games involve routines and repetitive formulate, which may be part $\mathrm{f}$ their charm for young children who often relish the familiarity of favorite activities.

Every learners enjoys games. They like interesting activities such as play, fun and cooperation that are included in games. One of the characteristics of game is that they involve repetition and repetition is basic in foreign language learning. Games can make the children do not feel bored with the lesson that the teacher explains, because the children will feel this is not just a kind of lesson but it will also entertain them to be happy and enjoy the class. That is why games are so useful and so important. It is not just because there are fun. It is partly because the fun element creates a desire to communicate and partly because games can create unpredictability.

Looking of the statements above, the writer interests to combine the applying of games and songsto increase students' English vocabulary.Julia Dobson(2012)said that: "Games are a great way to solve problems. Regular action in classprovides fun and relaxation. " The meaning of games are a way to relax class routines for fun. Moreover, as stated in the book Game for Language Learning: 'Game' for an entertaining and engaging activity, often challenging, and an activity in which students play and usually interact with other people ". This means that any action is gripping because Games can make students enthusiastic about playing, sometimes challenging. After all, when students play a game, they have to be the winner in that game, and it is also very entertaining because the students are fun and enjoy playing and interacting with each other. Besides that, it also provides opportunities for students to express their feeling.

While the popularity of pop songs can motivate students to learn languages (Limbong, 2012). Students will be more interested in learning through English songs which are considered fun and not boring. Some of the new vocabulary gained from the song lyrics. Memorizing English songs is a way that allows students to repeat and remember vocabulary. Besides, although most students consider learning by listening to English songs as entertainment, they also know spontaneously and unconsciously, which is a much more fun and efficient way to raise language awareness than memorizing vocabulary and grammar course books, which is mechanically boring (Shen, 2003).

The previous study in the Improving Students' Vocabulary Mastery using English Song. Written by Intan Permata Sari, Elva Elvinna Asahra and Yana ( IKIP 
Increasing Students' English Vocabulary by Applying Games and Songs at the Seventh Grade of SMP Negeri 8 Komodo

SILIWANGI, 2019 ) noted that the used of song may have a possitive effort to the students vocabulary. The researcher techniques was memorizing English-language songs in the teaching-learning process. The results were compared with the designed success criteria. The criteria for success were achieved.

The other previous study conducted by Miftahul Jannah with the title Using Games in Improving Students' Vocabulary. (Faculty of Tarbiyah and Teachers' Training "Syarif Hidayatullah" State Islamic University Jakarta, 2011). This study noted that there was a significant improvement in students' achievement after they taught English vocabulary using games. The students' responses showed that they were interested in learning vocabulary through using games.

Based on the background above, the writer states the problem of the study as follow: (1) How can games and songs be applied to improve the students'Englishvocabularyat the Seventh Grade of SMP Negeri 8 Komodo? And (2) How are the students' perceptions in applying games and songs to increase theirEnglish vocabulary?

Related to problem of the study above, the objective of this study as follow: (1) To describe the application of Games and Songs can improve students' vocabulary at the Seventh Grade of SMP Negeri 8 Komodo. And (2) To describe the students' perception in applying games and songs to increase their Englishvocabulary

\section{METHOD}

\section{Subject of the Research}

The subject of research was seventh grade of SMPN 8 Komodo, involving 23 students with 13 females and 10 males in academic year of 2020/2021.

\section{Research Design}

This research was Classroom Action Research (CAR). Action research was conducted by researchers with a vies to improve the professional practice of researchers and understand it better (Cameron-Jone, 1983). There are four stages of each cycle, they are: (1) The planning of the action , (2) the implementation of the action, (3) classroom observation and (4) reflecting of the action (Kemmis \& Taggart, 1988).

Kemmis and MCTaggart (1988) in Burns (2010:8) propose a model of a classical action research. There were some other models of action research, but they 
Increasing Students' English Vocabulary by Applying Games and Songs at the Seventh Grade of SMP Negeri 8 Komodo

were criticized by Kemmis and MCTaggart as being to fixed and inflexible. Regardless of the criticisms, it was a useful model because it expresses briefly the more important ideas about the essential phases in an action research study. Hence, the researcher selected to use it as a way in conducting an action research study.

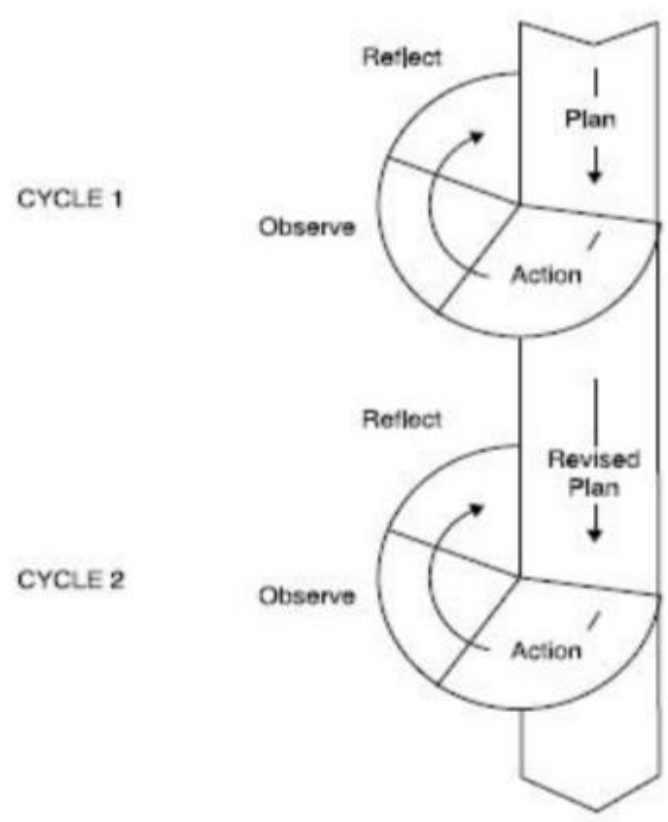

Figure 1. The Cyclical AR designed by Kemmis \& Taggart (1988)

\section{Technique of Data Collection}

This research was used qualitative descriptive approach. The data collection by using a set of test, questionnaires and observation sheets.

\section{Technique of Data Analysis}

The analysis qualitative data used in this study is the observation of students'activities during teaching learning process. Made a set of test in the cycle 1 and 2, then analyzed the quantitative data, the writer took the average of students'vocabulary score in cycle 1 and 2. It is used to measure how well students' English achievement onvocabulary. After that, the writer analyzed whetherthere wereany improvement of students' vocabulary score from average score in cycle 1 and cycle 2 or not. 
Increasing Students' English Vocabulary by Applying Games and Songs at the Seventh Grade of SMP Negeri 8 Komodo

\section{Criteria of Success}

This research was able to be called successful if itfulfilled the minimum criteria which have been determined, fail if it could not fulfill the criteriawhich have been determined and the minimum completion of criteria (KKM) was 72 .

In this study, based on the agreement between the researcher and the Englishteacher, when there is $70 \%$ of students achieve any improvement; gaining score 72 (seventy) of vocabulary test, means that this research could be called success. Then the next actionwould be stopped, but if this condition has not been reached yet, the alternative actionwould be done in the next cycle.

\section{FINDINGS}

\section{Cycle 1}

\section{Planning}

In the planning stage, the researchers prepared the research instruments, designed the lesson plans, selected the games and songs, set the criteria of success and made the research schedule.The researchers also made the evaluation form to know about students' achievement at the end of this cycle.

\section{Implementing}

In this section, the researcher applied the treatment to the students based on the lesson plan prepared. There are some steps planned toapply Games and English songsin teaching vocabulary. The steps are: (1) playing the song, (2) ask the students to do listening exercise given in the students' worksheet and discuss the answer together, (3) lead the students to sing the song line by line until the students could memorize the song and could sing independently, and (4) lead the students to sing the song together with some fun supportive activities. Besideof that, the teacher used games to measure students' vocabulary memorizing. Moreover, the teacher handled all of the activities in the classroom during this action. To make clear what happens in every meeting.

In the classroom, the material given about adjective. The researcher asked the students about their favorite English song. The song played first was You areMy sunshine by Jasmine Thompson. It was played 3 times. First playing aimed the students can enjoy music first. After that, the teacher was delivered the sheets contain songlyrics in missing word and asked students to fill it. Then the students have to collect the sheets 
and to make them memorizing the word lyric, Tic Tac Toe gameswas used.

\section{Observing}

In this study, the observation of students' new vocabulary mastery was conducted to obtain data and to find out about how well the applying of games and songs could achieve the research objectives. In this stage, researchers collected data related to the implementation of actions using several instruments. The first was observation sheets thatfilled by the observer. This instrument was used to gain the data related to the students' participation. The second was the result of vocabulary tests conducted by students at the end of each cycles, it aims to obtain data about student vocabulary mastery. The third was the result of a questionnaire given to students at the end of the study, which aims to find information about student responses to the applying of games and songs in teaching vocabulary.

\section{Reflection}

The researcher and the teacher discussed about the result of implementing the action. Then, they tried to analyze the data. The results show that only $20 \%$ students who passed the KKM. The researcher develops another effort to improve students' vocabulary. Beside of that, the students seemed to accept the material easily and enthusiastically by using game and songs. From the reflecting phase above, there must be more efforts to develop students' vocabulary by using game. It needed to be improved again in the next cycle. This effort was done in the next lesson plan of cycle two.

\section{Cycle 2}

\section{Planning}

The planning phase of the second cycle was implemented into a lesson plan. In this case, the writer planned the other strategies to improve their vocabulary, and the writer modified the lesson plan based on the phase in the first cycle. The lesson plan used still related to apply games and songs in increasing students' vocabulary.

\section{Implementing}

In this meeting, the students were taught about adjective again. Here, the teacher tried to change the treatment. In this section, the teacher gave the explanation about the material first. After that, the teacher played the song. The song played in many times. The teacher gave the students a sheet which contain missing lyric, students had to answer the word. While they fulfilled it, the teacher also made an expression of the 
Increasing Students' English Vocabulary by Applying Games and Songs at the Seventh Grade of SMP Negeri 8 Komodo

word they needed. For example, they try to guest the word "bad", so the teacher had to express "bad" in front of the class. In the last minutes, they had to collect the sheets.

\section{Observing}

In this phase, the researcher done the same activities as in cycle 1

\section{Reflection}

After knowing the result of vocabulary test and analyzing the data in the second cycle, the researcher realize that the target has been reaching where minimally $75 \%$ students who passed the KKM, therefore the researcher decided to stop the CAR because it had already succeeded. Hence, the writer did not revise the plan yet, because every action was planned as good as possible, so that teaching learning activities could be accomplished well.

\section{RESULTS}

Table 1. Test result in Cycle 1 and Cycle 2

\begin{tabular}{|l|l|l|l|l|}
\hline No & Cycle 1 & Score & Cycle 2 & Score \\
\hline 1 & The highest score & 80 & The highest score & 95 \\
\hline 2 & The lowest score & 35 & The lowest score & 60 \\
\hline 3 & The average score & 57,5 & The average score & 77,5 \\
\hline
\end{tabular}

Based on the scores obtained,the students' achievement in Cycle I was 57.5, and the average score of the Cycle II was 77.5. means that in cycle II reached the target score has reached. The target score is72 (KKM). Therefore, the research will not continue to cycle III.

\section{CONCLUSION}

Based on the results, the study was conducted in 2020/2021 in SMPN 8 Komodo 7th grade. Using games and songs can increase students' vocabulary. As shown by the following fact. First, the average Cycle I score was 57.5, and the Cycle II average was 77.5. It is proven that games and songs help students learn English, especially vocabulary. To learn vocabulary through games and songs is more fun for students, and songs help them memorize vocabulary easily. Third, the interview results show that the students enjoy using this method and are eager to attend English classes. 
Increasing Students' English Vocabulary by Applying Games and Songs at the Seventh Grade of SMP Negeri 8 Komodo

\section{REFERENCES}

Andrew Wright, David Betteridge and Michael Buckby, Games for Language Learning, (Cambridge University Press 2006). P.1

Agustina, R. K. (2016). Mastering English Vocabulary Skill by Using Song to The Second Semester Students' of Accountancy Department in Hasyim Asy'ari University of TebuirengJombang. Ed-Humanistics: JurnalIlmuPendidikan, $1(2)$.

Bridge, C. A., \& Burton, B. (1982). Teaching Sight Vocabulary Through Patterned Language Materials. New Inquiries in Reading Research and Instruction, 119-123.

Cameron-Jone, M. (1983). A Researching Profession? The Growth of Classroom Action Research. Scotland: Moray house College of Education.

Cameron, L. (2001). Teaching languages to young learners. Ernst KlettSprachen.

Cebula, D. 2008. Songs and Rhymes in Language Teaching Available at http://iatefl.org.pl/tdal/n9songs.htm. Accesed on November 19, 2016.

Dewi, N. P. (2013). Using English Song Memorization Technique to Improve The Seventh Graders' Mastery of Vocabulary. Jurnal Online UniversitasNegeriMalang, (January 2013), 1-12.

Griffe, D.T. 2001. Songs in Action. Hertfordshire: Prentice Hall International.

Gushendra, R. (2017). An Experimental Study: Improving Students' Vocabulary Mastery by Using English Songs. Indonesian Journal of Integrated English Language Teaching, 3(1), 53-64.

Kemmis, S., \&McTaggart, R. (1988). The Action Research Planner, 3rd. Victoria: Deakin University.

Limbong, R. (2012). Enriching Students' Vocabulary Using English Pop Songs. Journal of English Teaching, 57, 223-237.

Nurdiansyah, D. M. R., Asyid, S. A., \&Parmawati, A. (2019). Using Color Coding To Improve Students'english Vocabulary Ability. Project (Professional Journal Of English Education), 2(3), 358-363.

Setia, R. 2012. English Song as Means of Aiding Students' Proficiency Development, Online, www.ccsenet.org/ass, accessed on February 13, 2017.

Shen, C. (2003). Using English Songs: An Enjoyable and Effective Approach to ELT. English Language Teaching, 2(1), 88-94. 